\title{
Root Distribution and N Acquisition in an Alfalfa and Corn Intercropping System
}

\author{
Guiguo Zhang ${ }^{1,2}$, Chongyu Zhang ${ }^{1}$, Zaibin Yang $^{1} \&$ Shuting Dong ${ }^{2}$ \\ ${ }^{1}$ Department of Animal Sciences and Technology, Shandong Agricultural University, Tai-an, Shandong, P. R. \\ China \\ ${ }^{2}$ Key Laboratory of Crop Biology of China, Department of Agronomy, Shandong Agricultural University, Tai-an, \\ Shandong, P. R. China \\ Correspondence: Shuting Dong, Key Laboratory of Crop Biology of China, Department of Agronomy, Shandong \\ Agricultural University, Tai-an, Shandong, P. R. China. Tel: 86-0538-824-1257. E-mail: zhang3602@hotmail.com
}

Received: July 1, 2013 Accepted: July 23, 2013 Online Published: August 15, 2013

doi:10.5539/jas.v5n9p128 URL: http://dx.doi.org/10.5539/jas.v5n9p128

\begin{abstract}
Little attention has been paid to root distribution in combined perennial legume and annual cereal crops. The main objectives of this study were to explore the regularity of root distribution and the influence on nitrogen $(\mathrm{N})$ acquisition in different alfalfa (Medicago sativa L.) and corn (Zea mays L.) intercropping patterns. A three year (2007-2009) field experiment studied four intercropping patterns of alternating alfalfa and corn rows with alfalfa:corn rows sown at 2:2, 3:2, 4:2, and 5:2. Sole crops of corn and alfalfa were used as controls. Roots were sampled over 3 consecutive years by auger sampling method in the prime filling stage of corn from different soil depth, and the root length density (RLD) was used to describe the root spatial distribution of intercropped alfalfa and corn. The results showed that the alfalfa/corn intercropping system had the greater RLD values compared to the sole cropped alfalfa or corn. In addition, the root mass centre of intercropped alfalfa descended into deeper soil layers with advancing stand age, and likewise proliferated laterally towards associated corn rows. Whereas the corn root mass spread at relative shallow soil profile, and also more deployed laterally to neighboring alfalfa root zone. The gap between alfalfa and corn rows was the highest colonized area with greater intermingling and the highest RLD of both species root. The complementary and compatibility of the root spatial distribution of component crops in alfalfa/corn community were the essential cause for better biomass yield.
\end{abstract}

Keywords: alfalfa, corn, intercropping, root distribution, $\mathrm{N}$ acquisition

\section{Introduction}

The continued development and destruction of arable land is a serious threat to the world's food supply for both humans and livestock. Intercropping has shown great potential for increasing biomass yield in addition to reducing chemical fertilizer and pesticide input as well as increased biodiversity and land sustainability. Intercropping is thus considered to be a feasible strategy to relieve the food and feed crisis (Lenné \& Thomas, 2006; Carrubba et al., 2008; Kn Rzer et al., 2009). Almost all previous studies involving alfalfa (Medicago sativa L.)/corn (Zea mays L.) (Smith \& Carter, 1998), soybean (Glycine max L. Merr.)/wheat (Triticum aestivum L.) (Li et al., 2001), and alfalfa/wheat (Skelton \& Barrett, 2005) intercropping have documented superior production and land sustainability compared to sole crops. It has frequently been proposed that the co-existence of different crop species may produce shoots with complementary architectures so as to result in improved radiation interception and possibly high rates of photosynthesis, this would reduce resource competition (Wardle \& Peltzer, 2003). However, few experimental studies have explored in detail root distribution and interaction in intercropping systems, especially for the perennial/annual combination.

Some studies demonstrated that root interaction had a greater effect than shoot interaction on crop growth performance and resource capture in intercropping systems (Zhang \& Li, 2003; Li et al., 2006; Zhang et al., 2013). For legume/cereal intercropping in particular, the complementary spatial distribution of roots in the soil profile determined the ability of a crop to acquire the nutrients and the water necessary to sustain growth (Li et al., 2006; Gao et al., 2010). Furthermore, root distribution and interaction in intercropping systems were also responsible for the close relationships between community performance and $\mathrm{N}$ acquisition by component crops (Morris and Garrity, 1993a; Li et al., 2001). The root intermingling of component crops resulted in bidirectional transfer of N 
between intercropped legumes and cereals, thus allowing for a reduction in amount of $\mathrm{N}$ fertilizers applied while optimizing N nutrition within the intercrop (H Gh-Jensen \& Schjoerring, 2010; Zhang et al., 2013). Zhang and Li (2003) documented that interspecific below-ground interactions accounted for one-third of the yield increase, and about half the $\mathrm{N}$ uptake increase in some cases (Zhang \& Li, 2003).

Alfalfa is a perennial deep-root forage crop while corn is a seasonal dual-purpose crop producing human food and livestock fodder. Some published studies attempted to clarify the reasons for enhanced productivity of alfalfa/corn combination and generated multiple theories, including the effects of alternating growing stages of component crops, and compatible or complementary above-ground architecture and resource requirements (Smith \& Carter, 1998). However, information on root distribution is still lacking in these hypotheses. Elsewhere, Adiku et al. (2001) reported that corn roots traversed into the intercropped cowpea (Vigna sinensis L.) root zone, and that cowpea roots also proliferated into the corn root zone, but to a lower extent (Adiku et al., 2001). When corn was grown with wheat, lateral corn root growth was restricted to $20 \mathrm{~cm}$ compared to $40 \mathrm{~cm}$ when grown next to another corn row. When grown with faba beans (Vicia faba L.), corn roots spread to deeper soil layers beneath the faba bean root zone, and the faba beans showed abnormally shallow root distribution (Li et al., 2006). All these studies revealed that root spatial distribution pattern in intercropping systems was influenced not only by common environmental factors like soil properties, precipitation, and management, but much more by the interactions between the component crops (Lopez-Zamora et al., 2002; Ong et al., 2002).

In a perennial legume and seasonal cereal intercropping system, the below-ground root interaction determines the root spatial distribution pattern within a soil horizon, and further affects the $\mathrm{N}$ uptake and above-ground dry matter (DM) yields (Carlsson \& Huss-Danell, 2003). Thus, it is essential to ascertain the root distribution in order to understand $\mathrm{N}$ acquisition and the mechanisms responsible for the higher productivity reported in intercropping systems. It was previously reported that alfalfa/corn intercropping systems had a biomass yield advantage relative to the sole crop system, and that alfalfa was the superior component crop (Zhang et al., 2011). Smith and Carter (1998) indicated that alternating growing stages of component crops, complementary above-ground architecture and resource requirements contributed to the greater production performance for alfalfa and corn strip intercropping. However, root distribution of the widely practiced alfalfa/corn intercropping system has not been studied in detail. Alfalfa is a perennial legume forage, and its root distribution within the soil profile is significantly different to that of annual crops (Vance et al., 1979; Li et al., 2006). A full exploration of the underground root distribution and interaction in the soil horizon is vital for a better understanding of influence of intercropping patterns on community yield in different alfalfa/corn intercropping patterns.

Based on our prior findings in this combination (enhanced DM yield, alfalfa was the superior competitor, zhang et al., 2011), we hypothesized that some variations may be observed in the root deployment pattern in alfalfa/corn intercrops and that such variations would correspond to the yield advantage of the alfalfa/corn intercropping system. Hence the objectives of the current study were to ascertain (1) whether the component crops in alfalfa/corn intercropping had greater root proliferation and increased RLD at different soil layers (depth) compared to respective their sole crops, (2) whether alfalfa and corn root mass alternatively distribute in different soil depths in vertical orientation and colonize greatly in horizontal direction, producing the compatible and complementary root spatial configuration, and (3) whether there is variation in root mass central distribution of component crops with the advancing of stand age.

\section{Materials and Methods}

\subsection{Plant Materials and Experimental Design}

The field experiment was performed during 2007, 2008, and 2009 at the Chinese National Huang-Huai-Hai Regional Corn Technology Innovation Centre (36 $\left.09^{\prime} \mathrm{N}, 117^{\circ} 09^{\prime} \mathrm{E}\right)$ on a brown Alfisol (a loam, fine, mixed, super-active, mesic). The region has a temperate, semi-arid, and continental climate. Annual sunshine duration is 2 $611 \mathrm{~h}$. The frost-free period is about 200 days. Organic matter, total N, Olsen P, and K in the upper $20 \mathrm{~cm}$ of soil in the experimental field were $18.1,3.45,31.64$, and $78.20 \mathrm{mg} / \mathrm{kg}$, respectively. The rainfall and air temperature during the three experimental years were not greatly different between growing seasons; a detailed description of weather parameters for the three years (2007-2009) is given in Zhang et al. (2011).

Four intercropping treatments were replicated three times using a randomized complete block design. The intercrop treatments included different alternating rows of corn (Zea mays L. cv. 'Zhengdan 958') and alfalfa (Medicago sativa L. cv. 'Algonquin'). The seeds of alfalfa and corn used in this trial were all provided by the Corn Research Center of Shandong Agricultural University. The patterns were (i) two rows (40 $\mathrm{cm}$ wide) of alfalfa alternated with two rows $(80 \mathrm{~cm}$ wide) of corn or $2: 2$, (ii) three rows $(60 \mathrm{~cm}$ wide) of alfalfa alternated with two rows of corn or 3:2, (iii) four rows ( $80 \mathrm{~cm}$ wide) of alfalfa alternated with two rows of corn or 4:2, and (iv) five 
rows $(100 \mathrm{~cm}$ wide) of alfalfa alternated with two rows of corn or 5:2. The inter-row spacing was $20 \mathrm{~cm}$ for alfalfa and $40 \mathrm{~cm}$ for corn. There was a $30-\mathrm{cm}$ gap between alfalfa and corn strips (Figure 1). The intercropping areas occupied by alfalfa and corn were 33\%:67\%, 43\%:57\%, 50\%:50\%, and 55\%:45\%, respectively. Each plot was 6.5 $\mathrm{m}$ in length, and two bandwidths across; the intercropping plots areas were $15.6 \mathrm{~m}^{2}$ (i), $18.20 \mathrm{~m}^{2}$ (ii), $20.80 \mathrm{~m}^{2}$ (iii), and $23.40 \mathrm{~m}^{2}$ (iv), respectively. Adjacent plots were separated by a $0.4 \mathrm{~m}$ wide ridge. Prior to this experiment, the field had a crop of corn. Alfalfa was sown by hand at a seeding density of $22.5 \mathrm{~kg} / \mathrm{ha}$ on 3 April 2007 (thousand-grain weight, $2.3870 \mathrm{~g}$ ). The corn was sown by hand on 31 May each year at $60000 \mathrm{plants} / \mathrm{ha}$. Corn and alfalfa sole crops were used as control groups, and were planted at the same density as the intercropping plots. All plots were given similar applications of $\mathrm{N}(300 \mathrm{~kg} / \mathrm{ha})$ as ammonium nitrate and of phosphorus $(\mathrm{P})$ at $52 \mathrm{~kg}$ as calcium superphosphate and irrigated during the growing season to prevent water stress. The rates of fertilization were recommended by the local agronomists for intercropping systems, and are practiced by farmers in the region in order to replace the large amounts of $\mathrm{N}$ removed in the crops. All the $\mathrm{P}$ fertilizer and a half of the $\mathrm{N}$ was evenly broadcast and incorporated into the soil prior to sowing, the balance of $\mathrm{N}$ was further split into two applications applied at the elongation stage and the pre-tasselling stage for intercropped and sole cropped corn, at the reviving stage for established intercropped and sole-crop alfalfa.

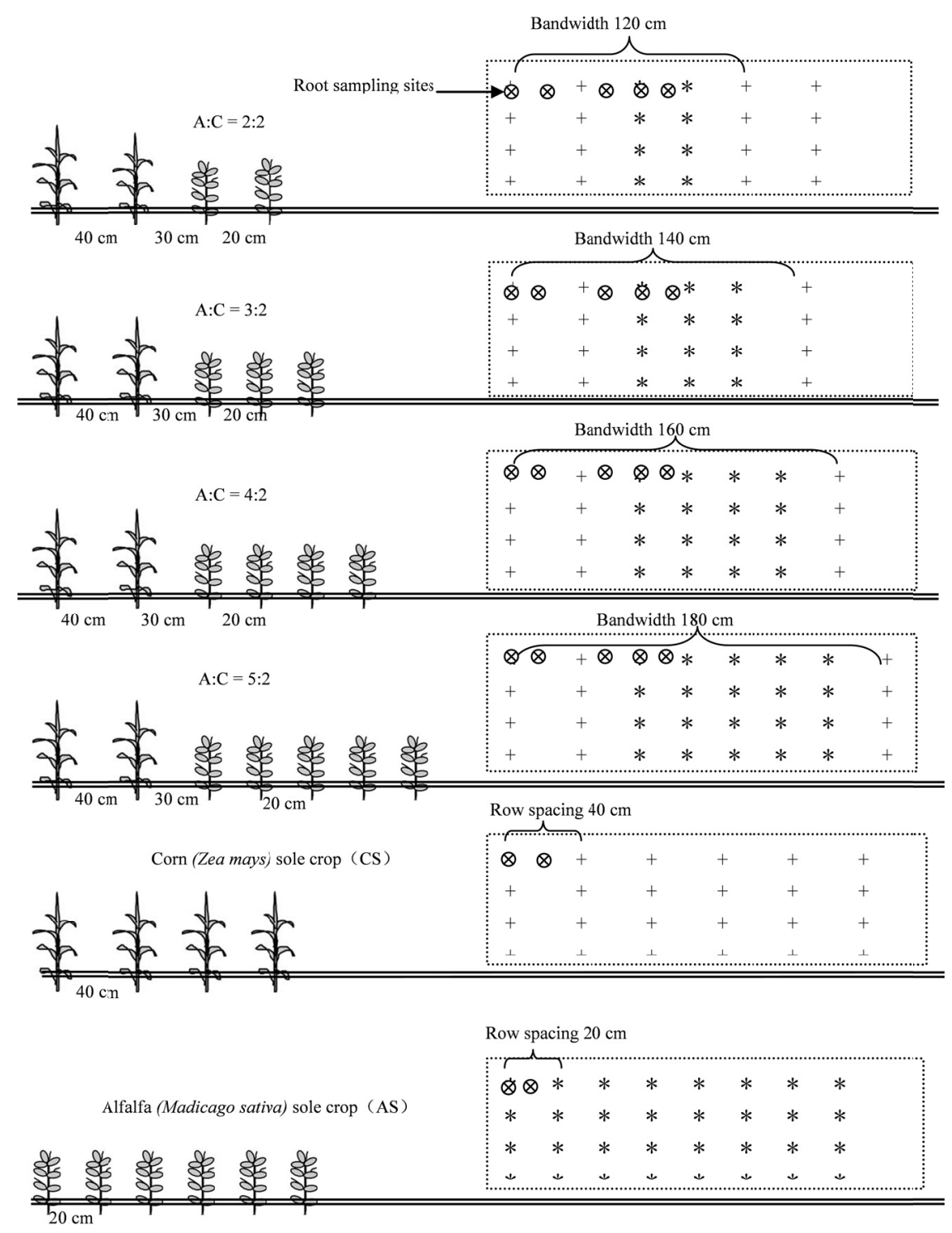

Figure 1. Diagram of different intercropping patterns between alfalfa $(\mathrm{A}, *)$ and corn $(\mathrm{C},+)$. Distances between rows and gap sizes $(\mathrm{cm})$ are indicated. Root sampling sites in each treatment are marked $(\otimes)$

\subsection{Nitrogen Acquisition by Intercropped Species}

Nitrogen acquisition was calculated as the product of the $\mathrm{N}$ content multiplied by the DM yields of the crops. 
Dry matter yields of alfalfa were measured by several harvestings at the early blooming stage (one-tenth bloom) each year. The harvested primary samples were oven-dried at $105 \pm 5{ }^{\circ} \mathrm{C}$ to measure the content of DM. The accumulated DM yield of all harvests was defined as the annual total biomass (Data of DM yields have been expressed in another article, Zhang et al., 2011). The grain and stalk of corn were harvested separately in the physiological maturity stage by cutting ten plants randomly from each plot. The grain and stalk DM yields of corn were determined in the same way as described for alfalfa. Nitrogen concentrations of alfalfa hay, corn grain, corn stalk, and whole corn plant were all determined by the micro-Kjeldahl procedure (Eastin, 1978).

\subsection{Determination of Root Length Density (RLD)}

Root samples were collected using the traditional auger sampling method (Li et al., 2006; Gao et al., 2010). It is commonly sampled several times to determine the dynamic variation of root distribution and development in a growing season in annual legume/cereal intercropping system ( $\mathrm{Li}$ et al., 2006; Gao et al., 2010). Alfalfa is a perennial legume and its roots mainly proliferate in the top $0-60 \mathrm{~cm}$ soil profile, and the root mass distribution varies by stand age. Corn is an annual cereal, with $85 \%$ of its fibrous root system distributed in the top $0-40 \mathrm{~cm}$ soil profile as an inverted cone shape, and root growth reaching a maximum at late blooming to early filling stage (Niu et al., 2010). Thus, in the present trial, we sampled the alfalfa and corn roots at the prime filling stage of corn in each year (10 August, 2007-2009, corn growth period 71 days). Root samples were collected at both intra- and inter-row regions (The sampling sites are illustrated in Figure 1). Root sample soil cores $(5 \mathrm{~cm}$ diameter $\times 20 \mathrm{~cm}$ depth) were collected at $0-20 \mathrm{~cm}, 20-40 \mathrm{~cm}$, and $40-80 \mathrm{~cm}$ depths from each replicate to determine the vertical root distribution. To investigate the horizontal distribution of roots, one corn row was selected as the starting point for collecting soil cores under one corn plant, and other root samples were collected in the horizon direction at 20,55,70, and $80 \mathrm{~cm}$ laterally (which extended into the inter-row between corn rows, the inter-row of alfalfa and corn rows, as well as the intra- and inter-row of alfalfa rows, Figure 1).

Each soil core collected was individually soaked in water for at least 1 hour, then stirred vigorously and poured through a sieve $\left(0.2 \mathrm{~mm}^{2}\right.$ mesh, $20 \mathrm{~cm}$ diameter and $10 \mathrm{~cm}$ height). The sieve was suspended in a large water bath and shaken continuously by hand until the roots were washed free of soil. Soil material remaining on the sieves was removed manually. The roots of alfalfa and corn were distinguished by their different colors, textures, and rooting patterns. The white corn root had smooth surfaces, brittle texture, and slight lignification, while the brown alfalfa roots had a harder texture and significant lignification. The collected root samples were put in white porcelain and root lengths were estimated by counting the number of intersections of roots with a $1-\mathrm{cm}$ mesh grid using the modified Newman-line-interest method (Tennant, 1975; Gao et al., 2010).

\subsection{Land Equivalent Ratio Based on Nitrogen Acquisition (NLER)}

The Nitrogen land equivalent ratio (NLER) can be calculated as the following formula (Giambalvo et al., 2011):

$$
\text { NLER }=\left(N_{i c} / N_{s c}\right)+\left(N_{i a} / N_{s a}\right)
$$

where $N_{i c}$ and $N_{s c}$ are the $\mathrm{N}$ yields of intercropped and sole cropped corn, and $N_{i a}$ and $N_{s a}$ are the $\mathrm{N}$ yields of intercropped and sole cropped alfalfa. A NLER of 1.0 indicates that $\mathrm{N}$ uptake by the intercropping system is equal to $\mathrm{N}$ uptake by the two sole crops. A NLER greater than 1.0 reveals an intercropping advantage over sole crops in terms of $\mathrm{N}$ acquisition. A NLER less than 1.0 suggests that the association of alfalfa-corn has no advantage over two components sole crops (Fetene, 2003; Wahla et al., 2009; Giambalvo et al., 2011).

\subsection{Nitrogen Competitive Ratio}

The N competitive ratio (CR) (Morris \& Garrity, 1993b; Li et al., 2001) was used to evaluate the competitive ability of different species in intercropping systems. It can be calculated by the following formula (Bhatti et al., 2006; Fan et al., 2006):

$$
C R_{a c}=\left(N_{i a} /\left(N_{s a} \times F_{a}\right)\right) /\left(N_{i c} /\left(N_{s c} \times F_{c}\right)\right)
$$

where $C R_{a c}$ is the competitive ratio of alfalfa relative to corn, $N_{i a}$ and $N_{i c}$ are the $\mathrm{N}$ acquisition per unit area of alfalfa and corn in intercropping, $N_{s a}$ and $N_{s c}$ are the yields per unit area of alfalfa and corn in sole cropping, and $F_{a}$ and $F_{c}$ are the proportions of the area occupied by alfalfa and corn in the intercropping. When $C R_{a c}$ is greater than 1 , the $\mathrm{N}$ take-up rate of alfalfa is higher than corn in the intercropping system.

\subsection{Statistical Analysis}

One-way analysis of variance (ANOVA) was performed according to the randomized complete block experimental design on the combined 3-year data set using SAS version 9.0 (Cole, 2001; SAS, 2002). Means between treatments and years were compared with Duncan's multiple-comparison range test at $5 \%$ level. 


\section{Results}

\subsection{Nitrogen Content and N Acquisition in Different Intercropping Patterns}

Considering the effects of the established year, the $\mathrm{N}$ content, regardless of alfalfa and corn (grain or stalk) sole crops or all intercropping treatments (pooled samples), did not present significant difference $(P>0.05)$ among years (Table 1). However, irrespective of establishment year, the grain $\mathrm{N}$ content of sole corn was always significantly $(P<0.05)$ higher than that of intercropping groups, in contrast, a significantly $(P<0.05)$ lower stalk $\mathrm{N}$ content of sole corn was observed compared with that of all intercropping treatments in each year. In addition, the $\mathrm{N}$ content of intercropped alfalfa (pooled samples) was consistent with the alfalfa sole crop $(P=0$. 543), except that the $\mathrm{N}$ content of alfalfa for 5:2 intercropping group was always greater $(P<0.05)$ than that of the sole crop over the three experimental years.

Differences in total $\mathrm{N}$ acquisition by alfalfa and corn were observed between sole crops and intercropping combinations, between patterns, and between years (Table 1). The $\mathrm{N}$ acquisition of grain, stalk, and corn (grain + stalk) was not significantly different $(P>0.05)$ from mono-cultured corn from 2007 to 2009 , whereas the total N acquisition of alfalfa grown in sole crops was significantly $(P<0.05)$ higher in 2008 and 2009 (after the stand was established) than in the sowing year (2007) (Figure 2). Additionally, the total $\mathrm{N}$ acquisition of all intercropping treatments (pooled samples) increased each year $(P<0.01)$ (Table 1), with significant $(P<0.05)$ improvements for each intercropping pattern with advancing stand age (Figure 2). The total $\mathrm{N}$ yields of alfalfa grown in pure stands and in all intercropped groups were always significantly $(P<0.01)$ higher than the $\mathrm{N}$ yields of sole crop corn during the three experimental years (Table 1). Nevertheless, comparison of total $\mathrm{N}$ acquisition between alfalfa sole crops and intercropping treatments exhibited some variations in different stand ages. In the sowing and the following years, the $\mathrm{N}$ yield of sole alfalfa was markedly $(P<0.05)$ higher than for all intercropping treatments. In the third year after establishment, the 5:2 treatment displayed a notably $(P<0.05)$ higher $\mathrm{N}$ yield relative to alfalfa monoculture. Taking account of all experimental groups, including component crops intercropping and monocultures, the total $\mathrm{N}$ acquisition per unit intercropped land increased linearly with land area occupied by alfalfa in the intercropping system for every year (Figure 3 ).

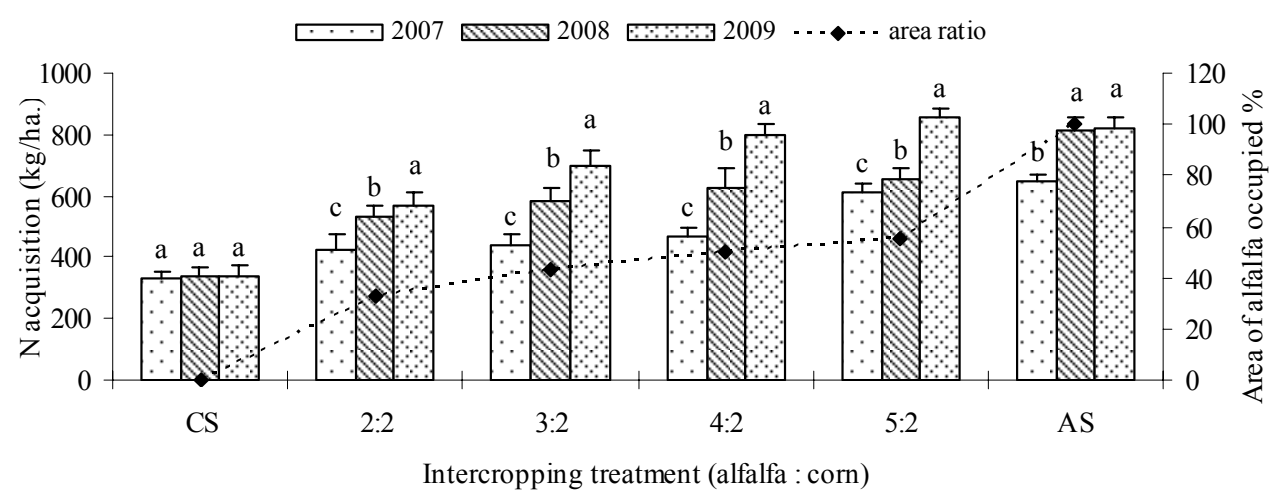

Figure 2. The comparison of $\mathrm{N}$ acquisition between the three growth years. All values are the mean $(\mathrm{n}=3) \pm \mathrm{SE}$ (bars) 


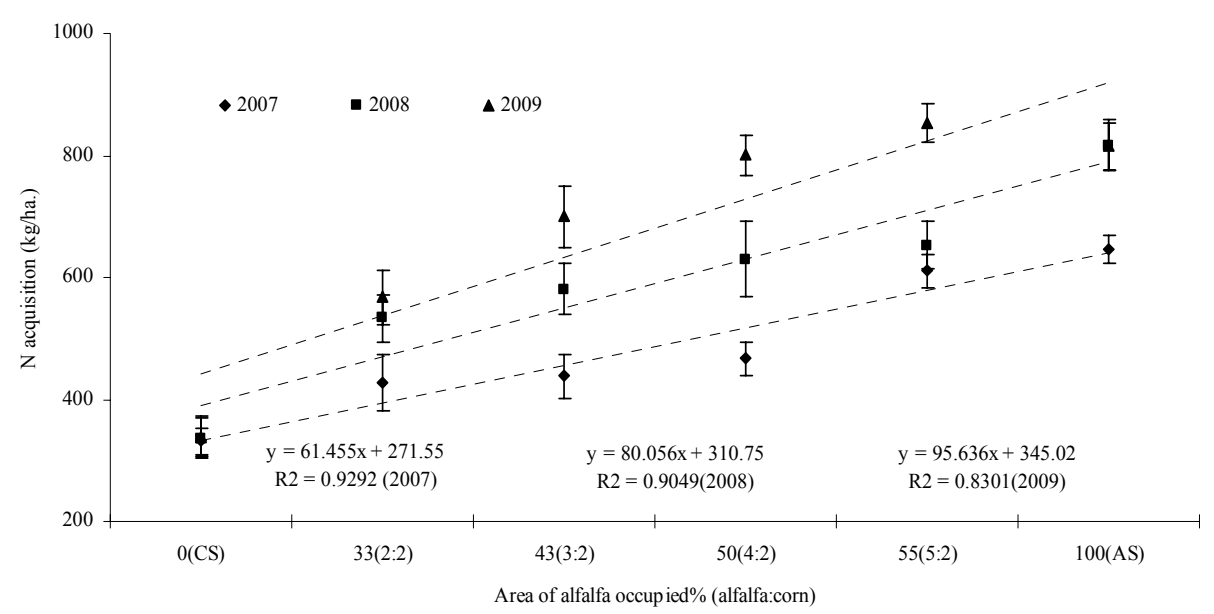

Figure 3. The dynamic variation in $\mathrm{N}$ acquisition as a function of the land occupied by alfalfa in different alfalfacorn combinations. All values are the mean $(n=3) \pm S E$ (bars)

Table 1. Nitrogen content of alfalfa, corn grain, stalk and $\mathrm{N}$ acquisition by alfalfa and corn in intercropping and sole cropping (monoculture) systems

\begin{tabular}{|c|c|c|c|c|c|c|c|c|c|}
\hline \multirow[t]{3}{*}{ Years } & \multirow[t]{3}{*}{ Treatments* } & \multicolumn{3}{|c|}{$\mathrm{N}$ content $\left(\mathrm{g} . \mathrm{kg}^{-1} \mathrm{DM}\right)$} & \multicolumn{5}{|c|}{$\mathrm{N}$ acquisition (kg/ha.) } \\
\hline & & \multirow[b]{2}{*}{ Alfalfa } & \multicolumn{2}{|c|}{ Corn } & \multirow[b]{2}{*}{ Alfalfa } & \multicolumn{3}{|c|}{ Corn } & \multirow[b]{2}{*}{ Sum } \\
\hline & & & Grain & Stalk & & Grain & Stalk & Total(grain +stalk) & \\
\hline \multicolumn{10}{|l|}{2007} \\
\hline & CS & & $18.03 \mathrm{a}$ & $9.91 b$ & l & $221.02 \mathrm{a}$ & $110.13 a$ & $331.15 \mathrm{a}$ & $331.15 \mathrm{e}$ \\
\hline & $2: 2$ & $37.80 \mathrm{~b}$ & $16.59 \mathrm{~b}$ & $10.34 \mathrm{a}$ & $217.71 \mathrm{e}$ & $134.84 \mathrm{~b}$ & $74.99 \mathrm{~b}$ & $209.84 \mathrm{~b}$ & $427.56 \mathrm{~d}$ \\
\hline & $3: 2$ & $36.21 \mathrm{~b}$ & $16.17 \mathrm{~b}$ & $13.53 \mathrm{a}$ & $285.73 d$ & $87.82 \mathrm{c}$ & $64.29 \mathrm{c}$ & $152.11 \mathrm{c}$ & $437.84 d$ \\
\hline & $4: 2$ & $36.28 \mathrm{~b}$ & $15.61 \mathrm{~b}$ & $10.00 \mathrm{a}$ & $327.27 \mathrm{c}$ & $88.21 \mathrm{c}$ & $51.39 \mathrm{~d}$ & $139.59 \mathrm{c}$ & $466.87 \mathrm{c}$ \\
\hline & $5: 2$ & $40.24 \mathrm{a}$ & $15.99 \mathrm{~b}$ & $10.01 \mathrm{a}$ & $467.58 b$ & $90.96 \mathrm{c}$ & $52.40 \mathrm{~d}$ & $143.39 \mathrm{c}$ & $610.97 \mathrm{~b}$ \\
\hline & AS & $35.98 \mathrm{~b}$ & & & $645.48 \mathrm{a}$ & 1 & l & I & $645.48 \mathrm{a}$ \\
\hline \multicolumn{10}{|l|}{2008} \\
\hline & $\mathrm{CS}$ & & $18.31 \mathrm{a}$ & $9.68 b$ & l & $227.21 \mathrm{a}$ & $108.38 \mathrm{a}$ & $335.59 \mathrm{a}$ & $335.59 \mathrm{e}$ \\
\hline & $2: 2$ & $39.45 \mathrm{a}$ & $16.44 \mathrm{~b}$ & $10.31 \mathrm{a}$ & $322.33 \mathrm{e}$ & $136.27 \mathrm{~b}$ & $74.25 b$ & $210.53 b$ & $532.86 \mathrm{~d}$ \\
\hline & $3: 2$ & $39.82 \mathrm{a}$ & $16.82 b$ & $10.24 \mathrm{a}$ & $388.65 \mathrm{~d}$ & $123.31 \mathrm{c}$ & $69.02 \mathrm{bc}$ & $192.33 \mathrm{c}$ & $580.98 \mathrm{c}$ \\
\hline & $4: 2$ & $39.29 \mathrm{a}$ & $18.54 \mathrm{~b}$ & $10.30 \mathrm{a}$ & $450.66 \mathrm{c}$ & $115.33 \mathrm{c}$ & $63.27 \mathrm{c}$ & $178.6 \mathrm{~d}$ & $629.26 \mathrm{~b}$ \\
\hline & $5: 2$ & $39.05 \mathrm{a}$ & $16.56 \mathrm{~b}$ & $10.57 \mathrm{a}$ & $513.11 \mathrm{~b}$ & $87.75 \mathrm{~d}$ & $51.58 \mathrm{~d}$ & $139.32 \mathrm{e}$ & $652.42 \mathrm{~b}$ \\
\hline & AS & $38.50 \mathrm{~b}$ & & & $814.59 \mathrm{a}$ & l & l & / & $814.59 \mathrm{a}$ \\
\hline \multicolumn{10}{|l|}{2009} \\
\hline & CS & & $19.02 \mathrm{a}$ & $9.68 b$ & l & $227.67 \mathrm{a}$ & $111.31 \mathrm{a}$ & $338.99 a$ & $338.99 \mathrm{e}$ \\
\hline & $2: 2$ & $37.19 b$ & $17.49 \mathrm{~b}$ & $12.98 \mathrm{a}$ & $315.71 \mathrm{e}$ & $152.49 \mathrm{~b}$ & $99.43 b$ & $251.92 b$ & $567.63 \mathrm{~d}$ \\
\hline & $3: 2$ & $39.35 \mathrm{ab}$ & $18.16 \mathrm{~b}$ & $12.46 \mathrm{a}$ & $461.2 \mathrm{~d}$ & $150.34 \mathrm{~b}$ & $88.98 \mathrm{c}$ & $239.32 b$ & $700.52 \mathrm{c}$ \\
\hline & $4: 2$ & $41.64 \mathrm{a}$ & $18.03 b$ & $11.10 \mathrm{a}$ & $583.85 \mathrm{c}$ & $141.93 b$ & $75.16 \mathrm{~d}$ & $217.09 \mathrm{c}$ & $800.94 \mathrm{~b}$ \\
\hline & $5: 2$ & $42.36 \mathrm{a}$ & $17.67 \mathrm{~b}$ & $12.70 \mathrm{a}$ & $666.25 b$ & $113.27 \mathrm{c}$ & $74.17 \mathrm{~d}$ & $187.44 d$ & $853.68 \mathrm{a}$ \\
\hline & AS & $37.06 \mathrm{~b}$ & & & $816.73 a$ & / & / & l & $816.73 b$ \\
\hline SEM & & & & & 26.335 & 5.623 & 3.354 & 8.578 & 33.163 \\
\hline \multicolumn{10}{|c|}{ ANOVA } \\
\hline \multicolumn{10}{|c|}{ Effects of years ( $P$-values) } \\
\hline & $\mathrm{CS}$ & / & 0.532 & 0.746 & & 0.176 & 0.630 & 0.330 & 0.330 \\
\hline & Pooled & 0.102 & 0.089 & 0.062 & $<0.001$ & $<0.001$ & $<0.001$ & $<0.001$ & $<0.001$ \\
\hline & AS & 0.056 & l & l & & & & & $<0.003$ \\
\hline \multicolumn{10}{|c|}{ Effects of treatments ( $P$-values) } \\
\hline & CS VS. AS & / & $<0.001$ & $<0.001$ & & & & & $<0.001$ \\
\hline & Pooled VS. CS & l & $<0.001$ & $<0.001$ & & $<0.001$ & $<0.001$ & $<0.001$ & 0.001 \\
\hline & Pooled VS. AS & 0.543 & l & l & $<0.001$ & & & & 0.004 \\
\hline
\end{tabular}

${ }^{\#}$ Different letters in the same column within each year indicate significant differences $(P<0.05)$.

${ }^{*}$ Treatment indicates alfalfa and corn row ratio (alfalfa : corn), in which CS means corn sole crop and AS means alfalfa sole crop. 


\subsection{LER Values Based on Nitrogen Acquisition (NLER)}

Differences of NLER values were also observed among different years and treatments (Figure 4). In the sowing year (2007), only the 5:2 intercropping treatment NLER value was always greater than 1.00 in terms of NLERg (based on corn grain $\mathrm{N}$ yield), NLERs (based on corn stalk $\mathrm{N}$ yield), and NLERt (based on total grain + stalk $\mathrm{N}$ yield), suggesting an $\mathrm{N}$ acquisition advantage. In the following two production years, however, all intercropping treatments showed $\mathrm{N}$ yields advantages based on NLER values greater than 1.00, irrespective of treatment, or plant sample (the $\mathrm{N}$ yield of corn grain, stalk, or total). Furthermore, the NLER value tended to increase for each intercropping treatment with each year of stand age (Figure 4). The 3 year average NLER values for all intercropping treatments were no less than 1.00 (range 1.00-1.26), revealing a $\mathrm{N}$ acquisition advantage for intercropping compared to sole crops. In addition, with the associated increase in alfalfa proportion in association, the NLER increased yearly (solid line indicates the variation tendency; Figure 4). Thus, the 5:2 intercropping treatment showed the best $\mathrm{N}$ yield advantage, which was consistent with the total $\mathrm{N}$ acquisition.

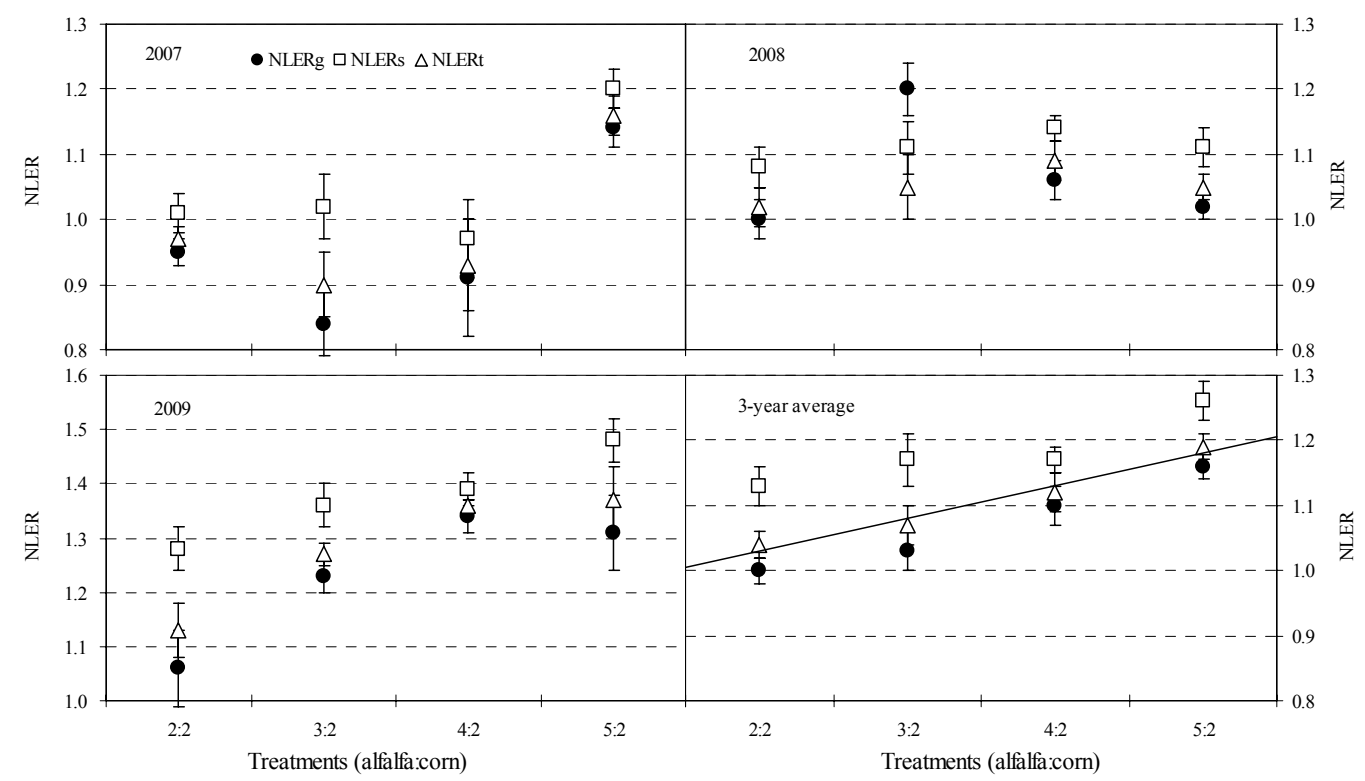

Figure 4. Comparison of $\mathrm{N}$ land equivalent ratio (NLER) of different intercropping patterns between years. NLERg, NLER are based on corn grain $\mathrm{N}$ yield; NLERs, NLER based on corn stalk $\mathrm{N}$ yield; NLERt, NLER based on total corn (grain + stalk) $\mathrm{N}$ yield. The solid line in 3-year average block diagram indicates the trend of NLER values between intercropped treatments. All values are the mean $(n=3) \pm S E$ (bars)

\subsection{Nitrogen Competitive Ratios}

Regardless of the intercropping patterns and the stand ages, the $C R_{a c}$ values always exceeded 1.0 (Table 2), and were higher than $C R_{c a}$ values during the 3-year period $\left(C R_{c a}\right.$ is the reciprocal of $C R_{a c}$, the values of $C R_{c a}$ are not listed). Furthermore, the average $\mathrm{N} C R_{a c}$ values over the three years was also higher than 1.0 for each intercropping configuration. In contrast, the average $\mathrm{N} C R_{c a}$ values were less than 1.0, suggesting that the greater $\mathrm{N}$ acquisition capacity of alfalfa relative to corn in alfalfa/corn combinations.

Table 2. Nitrogen competitive ratios of alfalfa relative to corn in different alfalfa/corn intercropping patterns

\begin{tabular}{cccccc}
\hline \multirow{2}{*}{ Years } & \multirow{2}{*}{$C R$ values } & \multicolumn{4}{c}{ Intercropping patterns (alfalfa:corn) } \\
\cline { 3 - 5 } & & $2: 2$ & $3: 2$ & $4: 2$ & $5: 2$ \\
\hline 2007 & $C R_{a c}{ }^{\dagger}$ & 1.08 & 1.28 & 1.22 & 1.31 \\
2008 & $C R_{a c}$ & 1.28 & 1.11 & 1.04 & 1.19 \\
2009 & $C R_{a c}$ & 1.06 & 1.06 & 1.12 & 1.17 \\
3-year average & $C R_{a c}$ & 1.14 & 1.15 & 1.13 & 1.23 \\
\hline
\end{tabular}

${ }^{\dagger} C R_{a c}$ : Competitive ratio of alfalfa relative to corn. 


\subsection{The Distribution of Roots Intercropped Species in Different Intercropping Patterns}

The variations of the alfalfa and corn root distribution in different cultivation patterns and stand ages are illustrated in Figure 5 and quantified by the corresponding RLD values. Independent of stand age and cropping pattern, the total RLD values referring to the sum of all depth determination $(0-80 \mathrm{~cm}$ soil depth) were always less in sole crop corn and alfalfa than for the corresponding component crops in each intercropping treatment. Based on the analysis of 3 year RLD values for corn sole crop, similar results were observed. In the vertical direction, 80 percent of the root mass was distributed to the upper $0-20 \mathrm{~cm}$ soil layer, about 15 percent was in the $20-40 \mathrm{~cm}$ soil horizon, and very little was found below the $40 \mathrm{~cm}$ soil depth during the 3 experimental years. In addition, the RLD values of corn sole crops in intra-rows (directly under corn plants) were greater than that in inter-rows $(20 \mathrm{~cm}$ laterally from the reference corn row). However, the root mass of all intercropped corn extended in the horizontal orientation to a greater extent in inter-rows and proliferated more deeply compared to sole crop corn, and even spread to the associated alfalfa root zone in some intercropping patterns such as 4:2 and 5:2, suggesting more lateral root growth of corn when intercropped with alfalfa. Likewise, the roots of mono-cultured alfalfa mostly existed in the intra-row (directly under the alfalfa plants), whereas the root mass centre extended into deeper soil profile with each passing year.

In the sowing year, the root mass of intercropped alfalfa mainly distributed in shallow soil layers irrespective of cultivated patterns (as indicated by the RLDs values), of which 70 percent distributed in the top 0-20 cm soil layer and about 20 percent distributed in the $20-40 \mathrm{~cm}$ soil horizon. The fibrous root of intercropped corn mainly extended in the upper 0-20 cm soil horizon, and few roots of corn occurred below the $20 \mathrm{~cm}$ soil depth. However, a small quantity of neighboring alfalfa and corn roots were found in the $0-40 \mathrm{~cm}$ soil layer in the gap between the alfalfa and corn rows (Figure 5, 2007).

In the year following establishment (2008), the RLDs of intercropped corn and alfalfa in each determined soil depth were all greater than the corresponding component crop in the sowing year independent of intercropping patterns. The root mass centre of intercropped alfalfa extended to $20-40 \mathrm{~cm}$ in vertical orientation, and quantities of roots proliferated laterally into the gap and into the corn root zone at $20-40 \mathrm{~cm}$ soil depth. As well, the total RLD in each soil layer was greater than that of the establishment year, whereas less spread into the corn root zone at 0 $20 \mathrm{~cm}$ below the corn row. Most of the root mass of intercropped corn distributed within the 0-20 cm soil depth under the corn row, and some corn roots spread laterally into the $20-40 \mathrm{~cm}$ depth under the gap between alfalfa and corn row, intermingling with the neighboring alfalfa roots. The total RLDs values were greater than that in the sowing year. The gap between alfalfa and corn rows had the highest root density (based on the greatest RLD values), suggesting a greater root extension and root overlap of component crops root in this area. Thus, the roots of the two associated crops expended a greater distance horizontally compared to the mono-cultured crops, resulting in the intermingling of associated crops. Consequently, the enhanced RLDs sum in the second year compared with the first year, indicating more lateral spread of component crop roots toward the associated crop row in the alfalfa-corn community (Figure 5, 2008).

In the third year after establishment (2009), the tap root mass centre of intercropped alfalfa moved down to below $40 \mathrm{~cm}$ (as indicated by higher RLDs values at this level), and much more alfalfa root proliferated laterally below the $20 \mathrm{~cm}$ soil layer under the neighboring corn row. In contrast, less corn roots mass was detected within associated alfalfa row root zone. In addition, from the RLD determination, there was a higher root density area in the gap between alfalfa and corn rows, and greater interspecific root intermingling in this area. The corn roots still mainly distributed in the $0-20 \mathrm{~cm}$ soil layer in both inter-row and intra-rows of corn, and less corn root was observed within the corn row at the $40-80 \mathrm{~cm}$ soil depth. Between the alfalfa rows and corn rows, however corn root alone and intermingling with the alfalfa root were found in and under the $20-80 \mathrm{~cm}$ soil layer, suggesting that in the border area of two component crops, there was more corn root proliferation in areas with alfalfa root, and spreading to deeper soil layers (Figure 5, 2009). 

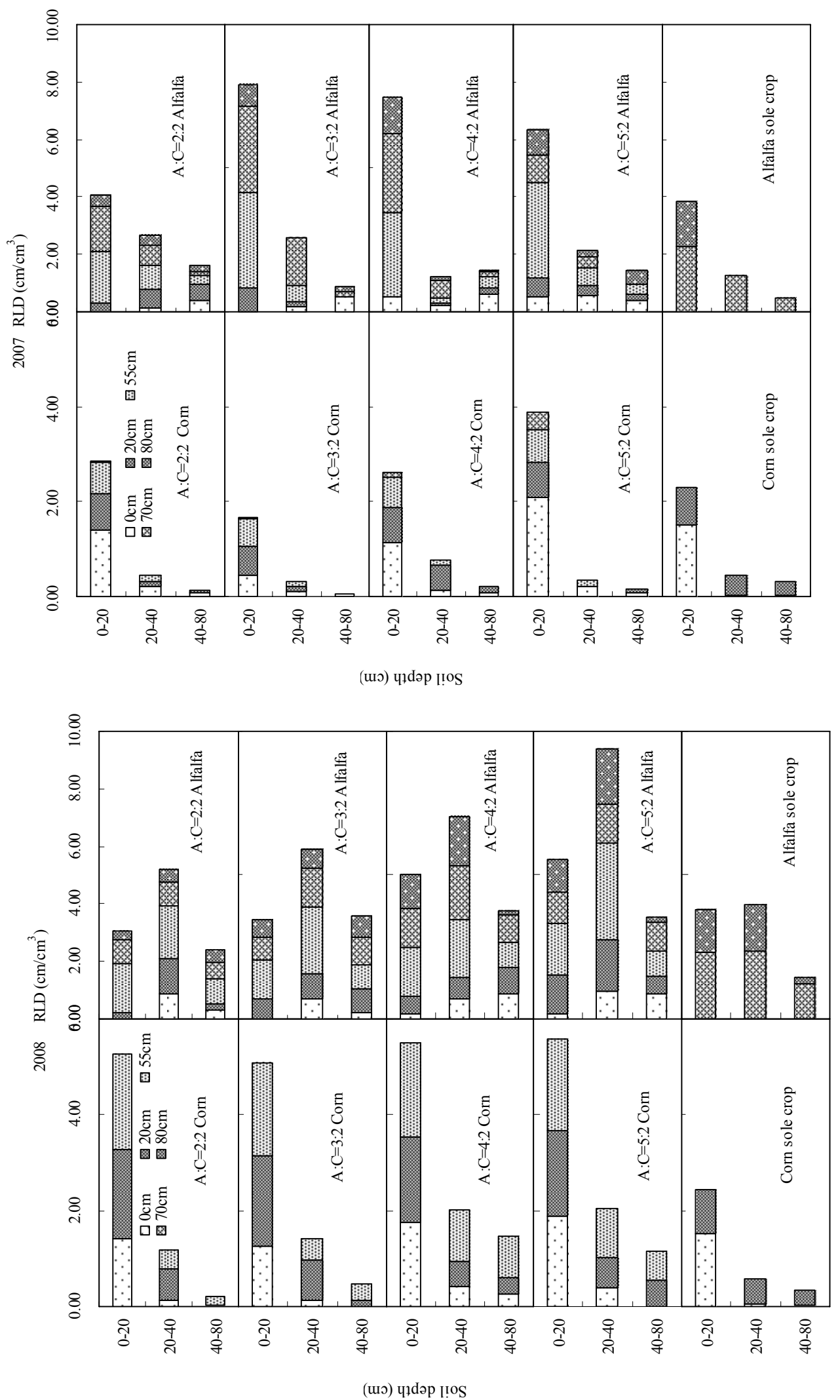


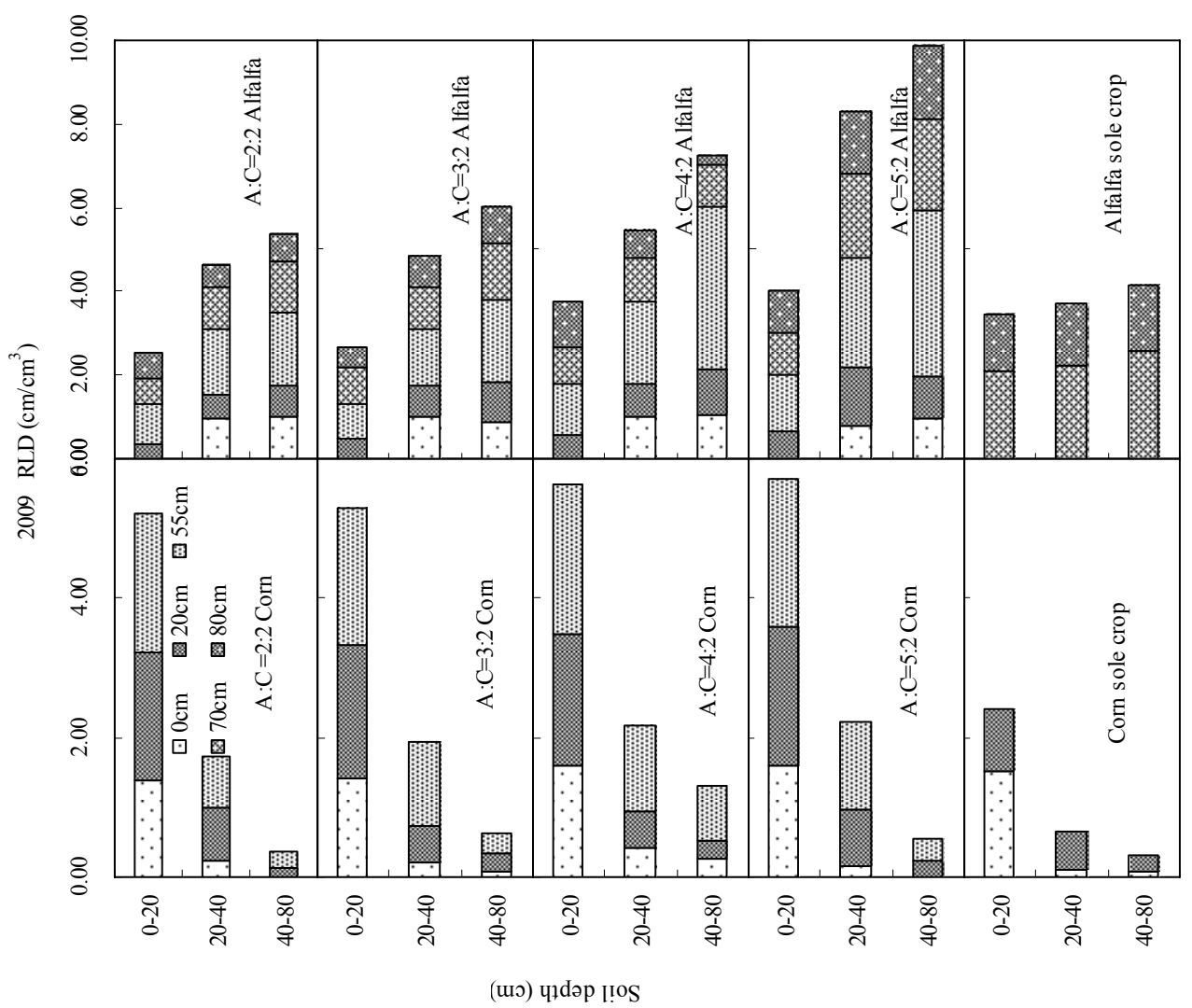

Figure 5. Root length density (RLD) at different horizontal and vertical distances from the reference point (3 years results). Taking a corn plant as a reference within a strip, $0 \mathrm{~cm}$ means a root sample below the corn row, similarly, $20 \mathrm{~cm}$ means the sampling point is at inter-row of corn, $55 \mathrm{~cm}$ is the inter-row point between corn and alfalfa, 70 $\mathrm{cm}$ is the intra-row of alfalfa, and $80 \mathrm{~cm}$ the inter-row of alfalfa

\section{Discussion}

In the present study, the $\mathrm{N}$ content was lower in corn grain and higher in corn stalk compared with that of the sole cropped corn. This indicated the intercropping of alfalfa and corn made the $\mathrm{N}$ deposited more proportion in stalk and less in grain, and therefore changed the $\mathrm{N}$ distribution in different organs. On the other hand, the higher $\mathrm{N}$ content of alfalfa in 5:2 intercropping treatment across all three years suggested that this intercropping pattern also enhanced above-ground $\mathrm{N}$ acquisition of alfalfa. Thus, the combination of corn and alfalfa affected the $\mathrm{N}$ uptake of component crops, as well as the $\mathrm{N}$ amount deposited in different organs of crops. Under the current experimental setting, the alfalfa in 5:2 intercropping configuration presented the highest $\mathrm{N}$ content in all growing years. Our findings were consistent with some previous reports. For example, Giambalvo et al. (2011) reported when the Berseem clove and annual ryegrass were grown together in alternating rows, there was a markedly higher $\mathrm{N}$ content in ryegrass hay compared to ryegrass grown in pure stand (Giambalvo et al., 2011). When the legume and cereal are grown in association to compose the intercropping system, the cereal would absorb more $\mathrm{N}$ directly form legume root rhizosphere, this in turn strengthen the $\mathrm{N}$ fixation capacity of legume, which may be a vital reason for the improved $\mathrm{N}$ content for both crops (Tomm et al., 1994).

In our study, the total $\mathrm{N}$ uptake of sole crop corn was not different over the years. This may be due to the small variation in environmental factors impacting growth, including precipitation and air temperature, over the years. While the $\mathrm{N}$ acquisition of sole cropped alfalfa was higher in the subsequent two years than in the sowing year, it was similar to the DM yield (Zhang et al., 2011), suggesting that alfalfa productivity entered the greater and stabile stage from the second year of establishment (Tomm et al., 1994; De Oliveira et al., 2004). The intercropping of alfalfa and corn increased the total $\mathrm{N}$ acquisition compared to the sole cropped crops.

Furthermore, the total $\mathrm{N}$ acquisition displayed a linear increase with the improved ratio of alfalfa in the intercropping system each year, indicating that inclusion of alfalfa in a corn monoculture system can improve the 
total $\mathrm{N}$ uptake of the community irrespective of what the intercropping proportion is. In addition, the total $\mathrm{N}$ acquisition increased each year, and for each intercropping pattern showed significant improvement with advancing stand age. This result revealed the intercropping pattern and stand age are important factors influencing the $\mathrm{N}$ yield of the community. The enhanced total $\mathrm{N}$ acquisition of all intercropping groups with stand age may stem from the increased DM yields and higher $\mathrm{N}$ content of alfalfa in harvested mixture. Regardless of the established year or intercropping patterns, the 5:2 intercropping pattern presented the optimal $\mathrm{N}$ acquisition advantage. Most published studies on intercropping system concluded that the association of legume-cereal can increase nutrient uptake and availability relative to sole cropping (Kn Rzer et al., 2009). Additionally, the increased biodiversity in intercropping systems also considered to be accounting for improved nutrient acquisition (Bessler et al., 2009). On the other hand, the interspecific niche compatibility and facilitation also contributed to resources efficient utilization (Whitmore \& Schröder, 2007).

The land equivalent ratio (LER) was introduced into intercropping system studies to compare the DM yield with that of the same component crops in sole crop (Willey \& Rao, 1980; Li et al., 1999). Dario Giambalvo (2011) used it as an index to assess whether an intercropping system was more efficient than sole crops by considering total $\mathrm{N}$ acquisition as defined by the $\mathrm{N}$ land equivalent ratio (NLER). In the sowing year, only the NLER of the 5:2 treatment was above 1, while in the two following year, all NLER values from intercropping groups exceeded 1. The averaged 3-year NLER values for all intercropping treatments were above 1 , revealing an advantage based on $\mathrm{N}$ acquisition of intercropping treatment compared to the component crops grown in sole crop. Similar to the variation of total $\mathrm{N}$ acquisition, the NLER increased in each intercropping treatment for each year, especially with higher alfalfa ratios. Therefore, the 5:2 group showed the best $\mathrm{N}$ yield advantage, which is consistent with the total $\mathrm{N}$ acquisition. In our study, the $C R_{a c}$ values were always higher than $C R_{c a}$ values based on total $\mathrm{N}$ acquisition, irrespective of intercropping patterns and stand ages, suggesting a higher capacity of alfalfa to capture $\mathrm{N}$ relative to associated corn. This indicates that alfalfa was the dominant species and a superior competitor in alfalfa-corn combination, and has a competitive advantage in acquiring $\mathrm{N}$ from the soil.

The $\mathrm{N}$ acquisition of crops is correlated with the distribution of root systems in legume-cereal intercrops (Mi et al., 2007). The higher the $\mathrm{N}$ acquisition of the crop, the greater the total root volumes and quantities of that crop has in cropping system (Tian et al., 2006; Mi et al., 2007). While the root vertical and horizontal distribution of component crops reflect the growing and developing conditions belowground, the root density in soil profile is closely related to the ability of a crop to acquire nutrients necessary to sustain plant growth (Li et al., 2006), which further influences the community performance and total nutrient acquisition. Of our findings that the enhanced total $\mathrm{N}$ acquisition of intercropping groups in 5:2 intercropping pattern may arise from the overlapping distribution and intermingling of the components crop roots. There is more lateral root growth of corn when intercropped with legumes than when intercropped with cereals or grown alone (Li et al., 2006). Prior study pointed out that the corn root spreading extent in soil profile that can be described by RLD is an important factor that effects the $\mathrm{N}$ acquisition of corn aboveground shoot (Peng et al., 2010). In addition, corn roots showed a greater extent of intermingling with intercropped legumes and greater lateral growth towards the legumes row (Li et al., 2006). The RLD is generally used as an index to assess the root spatial distribution pattern within a soil horizon, and the growing conditions of crops belowground have important effects on nutrient capture and production from an intercropping system (Ong et al., 2002; Gao et al., 2010). Analysis of the RLD values showed that, in the sowing year, the roots of intercropped alfalfa and corn rarely overlapped, thus reducing the belowground competition for soil nutrients and water. According to the physiological characteristics, from the following year after sowing, alfalfa started to enter the high-yield stage, and the roots extended into deeper soil layers. Also, the alfalfa root centre proliferated deeply in the vertical direction with each year (as reflected by the improved RLD values) irrespective of intercropping. This reduced the competition for soil mineral nutrients and water as would occur in upper soil layers in the intercropping system. Comprehensive analysis of the root distribution features in different alfalfa-corn combinations showed greater aggregated RLDs in the gaps between alfalfa and corn rows, revealing that the root masses of intercropped corn and alfalfa distributed and intermingling to a greater extent in these areas. This root intermingling strengthened interspecific facilitation rather than competition, because the exudation of nitrogenous compound from legume root zone would be partial absorbed by associated cereals, and the $\mathrm{N}$ transfer in turn stimulated the biological $\mathrm{N}$ fixation by legume. As a consequence, this led to improved total $\mathrm{N}$ uptake by alfalfa-corn intercrop systems (Tomm et al., 1994). The root intermingling also resulted in the interspecific competition for absorption of soil nutrients, which renders a decrease in soil $\mathrm{N}$ uptake by legumes, and correspondingly, a higher percentage of $\mathrm{N}$ derived from atmospheric $\mathrm{N}_{2}$, with improved the total $\mathrm{N}$ acquisition by the community (Xiao et al., 2004).

The roots of intercropped alfalfa and corn exhibited much greater growth in the horizontal direction. The root of 
intercropped alfalfa grew deeper than in alfalfa monocultures, and proliferated into the area under the corn row. This root pattern differed from the annual legume-cereal combinations. In corn-faba bean intercropping, the corn root spread under the faba bean row, whereas the roots of faba bean proliferated just in the upper soil (Li et al., 2006). Our findings indicated that corn roots mainly distributed in relative shallow soil layers compared to the associated alfalfa; however, some roots also spread laterally into deeper soil layers toward the neighboring alfalfa row. This contributed to much greater resource absorption from deeper soil layers. De Kroon (2007) reported that when two plants were grown together, the component crops can recognize the neighboring "nonself" root, and the extension of two non-homogenous root masses tends to greater into a mutual root neighborhood (De Kroon, 2007). In our study, alfalfa and corn roots in all intercropping patterns exhibited much greater proliferation in the horizontal direction and spread into the next lateral root zone compared to mono-cultured alfalfa or corn (the greater RLD values), resulting in greater intermingling of root. The root intermingling of intercropped cereal and legume benefited the cereal, allowing it to acquire much more $\mathrm{N}$ from the associated legume, which, in turn, stimulates the legume to fix $\mathrm{N}$ from the air. In addition, the distribution of plants roots was governed by the nutrient availability in soil layers (Fox, 1955). The intermingling and interaction of roots enhanced the nutrient content in the gaps between alfalfa and corn rows, and thus improved the total $\mathrm{N}$ of the community. Therefore, the spatial distribution and interaction of intercropped alfalfa and corn roots were influenced by intercropping patterns. On the other hand, the root conditions belowground would influence the $\mathrm{N}$ acquiring capacity of component crops (as reflected by $C R_{a c}$ and the total $\mathrm{N}$ acquisition indicated by NLER).

In the present study, the 5:2 intercropping pattern displayed a greater root spread in both the vertical and horizontal orientations based the analysis of RLD data. The root mass of alfalfa and corn in one community presented more complementation and compatibility than competition. Thus, the roots of alfalfa and corn were compatible and facilitated growth, which contributed to the higher total soil $\mathrm{N}$ uptake efficiency.

\section{Conclusions}

The combination of corn and alfalfa improved the $\mathrm{N}$ content of corn stalk and lowered the $\mathrm{N}$ content of corn grain compared with the sole cropped corn. The $\mathrm{N}$ content of alfalfa in 5:2 treatment was always higher than that of sole cropped alfalfa and other intercropping treatments over the 3-year trial. The intercrop of alfalfa/corn had higher $\mathrm{N}$ acquisition compared with sole cropped corn, as indicated by corresponding NLER values, and the amount of N acquired presented positive correlation with the land ratio alfalfa occupied. In addition, in the present study, the 5:2 treatment showed the highest $\mathrm{N}$ acquisition advantage. Alfalfa had greater ability of acquiring $\mathrm{N}$ from soil relative to corn, based on all the $C R_{a c}$ values exceeding 1 . The alfalfa root mass centre descended into deeper soil profiles in vertical direction with each passing year, irrespective of cropping patterns. Compared to sole cropped alfalfa, the root of alfalfa in alfalfa/corn intercrop occupied a greater soil volume based on higher RLD, and proliferated into a deeper soil layer underneath the associated corn plants. Some alfalfa root deployed into the $20-80 \mathrm{~cm}$ soil horizon under neighbor corn row. The root mass of sole cropped corn mainly distributed in 0-20 soil layer. However, the roots of corn in different intercropping treatments displayed a greater spread in vertical and horizontal orientations, and had higher RLD relative to mono-cultured corn at all determined soil depth. Furthermore, the root mass of in intercropped corn extended laterally to a greater extent towards the associated alfalfa row, and had greater colonization in the gap between alfalfa and corn strip accompanied with the alfalfa root grow to a deeper soil horizon. It was the highest root density zone of the gap between alfalfa and corn rows and had greater extent intermingling involving alfalfa and corn root for all intercropping configurations, referring to the significant higher RLD compared to the mono-cultured component crops. The root compatibility and facilitation of intercropped alfalfa and corn were the important causes for improved total $\mathrm{N}$ acquisition in alfalfa/corn community.

\section{References}

Adiku, S. G. K., Ozier-Lafontaine, H., \& Bajazet, T. (2001). Patterns of root growth and water uptake of a maize-cowpea mixture grown under greenhouse conditions. Plant Soil, 235, 85-94. http://dx.doi.org/10.1023/A:1011847214706

Bessler, H., Temperton, V. M., Roscher, C., Buchmann, N., Schmid, B., Schulze, E. D., ... Engels, C. (2009). Aboveground overyielding in grassland mixtures is associated with reduced biomass partitioning to belowground organs. Ecology, 90, 1520-1530. http://dx.doi.org/10.1890/08-0867.1

Bhatti, I. H., Ahmad, R., Jabbar, A., Nazir, M. S., \& Mahmood, T. (2006). Competitive behaviour of component crops in different sesame-legume intercropping systems. Int. J. Agric. Biol. (Pakistan), 8, 165-167. 
Carlsson, G., \& Huss-Danell, K. (2003). Nitrogen fixation in perennial forage legumes in the field. Plant Soil, 253, 353-372. http://dx.doi.org/10.1023/A:1024847017371

Carrubba, A., La Torre, R., Saiano, F., \& Aiello, P. (2008). Sustainable production of fennel and dill by intercropping. Agron. Sustain. Dev., 28, 247. http://dx.doi.org/10.1051/agro:2007040

Cole, S. R. (2001). Analysis of complex survey data using SAS. Comput. Meth. Prog. Bio., 64, 65-69. http://dx.doi.org/10.1016/S0169-2607(00)00088-2

De Kroon, H. (2007). How do roots interact? Science, 318, 1562. http://dx.doi.org/10.1126/science.1150726

De Oliveira, W. S., Oliveira, P. P. A., Corsi, M., Rodrigo, F., Duarte, S., \& Tsai, S. M. (2004). Alfalfa yield and quality as function of nitrogen fertilization and symbiosis with Sinorhizobium meliloti. Sci. Agric.(Piracicaba, Braz.), 61, 433-438.

Eastin, E. F. (1978). Total nitrogen determination for plant material containing nitrate. Anal. Biochem., 85, 591-594. http://dx.doi.org/10.1016/0003-2697(78)90259-2

Fan, F., Zhang, F., Song, Y., Sun, J., Bao, X., Guo, T., \& Li, L. (2006). Nitrogen fixation of faba bean (Vicia faba L.) interacting with a non-legume in two contrasting intercropping systems. Plant Soil, 283, 275-286. http://dx.doi.org/10.1007/s11104-006-0019-y

Fetene, M. (2003). Intra-and inter-specific competition between seedlings of Acacia etbaica and a perennial grass (Hyparrenia hirta). J. Arid Environ., 55, 441-451. http://dx.doi.org/10.1016/S0140-1963(03)00052-1

Fox, R. L. (1955). Subirrigation and Plant Nutrition I. Alfalfa Root Distribution and Soil Properties. Soil Sci. Soc. Am. J., 19, 468.

Gao, Y., Duan, A., Qiu, X., Liu, Z., Sun, J., Zhang, J., \& Wang, H. (2010). Distribution of roots and root length density in a maize/soybean strip intercropping system. Agr. Water Manage., 98, 199-212. http://dx.doi.org/10.1016/j.agwat.2010.08.021

Giambalvo, D., Ruisi, P., Di Miceli, G., Frenda, A. S., \& Amato, G. (2011). Forage production, N uptake, N 2 fixation, and $\mathrm{N}$ recovery of berseem clover grown in pure stand and in mixture with annual ryegrass under different managements. Plant Soil, 379-391. http://dx.doi.org/10.1007/s11104-010-0703-9

H Gh-Jensen, H., \& Schjoerring, J. K. (2010). Interactions between nitrogen, phosphorus and potassium determine growth and $\mathrm{N}$ 2-fixation in white clover and ryegrass leys. Nutr. Cycl. Agroecosys., 1-12. http://dx.doi.org/10.1007/s10705-009-9341-0

Kn Rzer, H., Graeff-H Nninger, S., Guo, B., Wang, P., \& Claupein, W. (2009). The rediscovery of intercropping in China: a traditional cropping system for future Chinese agriculture - a review. Climate Change,

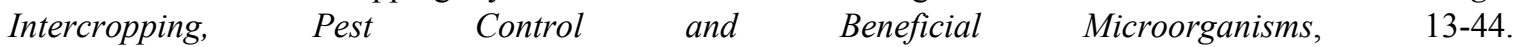
http://dx.doi.org/10.1007/978-90-481-2716-0_3

Lenné, J. M., \& Thomas, D. (2006). Integrating crop livestock research and development in Sub-Saharan Africa: Option, imperative or impossible? Outlook Agr., 35, 167-175. http://dx.doi.org/10.5367/000000006778536765

Li, L., Sun, J., Zhang, F., Guo, T., Bao, X., Smith, F. A., \& Smith, S. E. (2006). Root distribution and interactions between intercropped species. Oecologia, 147, 280-290. http://dx.doi.org/10.1007/s00442-005-0256-4

Li, L., Sun, J., Zhang, F., Li, X., Yang, S., \& Rengel, Z. (2001). Wheat/maize or wheat/soybean strip intercropping: I. Yield advantage and interspecific interactions on nutrients. Field Crop. Res., 71, 123-137. http://dx.doi.org/10.1016/S0378-4290(01)00156-3

Li, L., Yang, S., Li, X., Zhang, F., \& Christie, P. (1999). Interspecific complementary and competitive interactions between intercropped maize and faba bean. Plant Soil, 212, 105-114. http://dx.doi.org/10.1023/A:1004656205144

Lopez-Zamora, I., Falc O, N., Comerford, N. B., \& Barros, N. F. (2002). Root isotropy and an evaluation of a method for measuring root distribution in soil trenches. Forest Ecol. Manag., 166, 303-310. http://dx.doi.org/10.1016/S0378-1127(01)00679-X

Mi, G. H., Chen, F. J., \& Zhang, F. S. (2007). Physiological and genetic mechanisms for nitrogen-use efficiency in maize. J. Crop Sci. Biotech, 10, 57-63.

Morris, R. A., \& Garrity, D. P. (1993a). Resource capture and utilization in intercropping: water. Field Crop. Res., 34, 303-317. http://dx.doi.org/10.1016/0378-4290(93)90119-8 
Morris, R. A., \& Garrity, D. P. (1993b). Resource capture and utilization in intercropping: non-nitrogen nutrients. Field Crop. Res., 34, 319-334. http://dx.doi.org/10.1016/0378-4290(93)90120-C

Niu, J., Peng, Y., Li, C., \& Zhang, F. (2010). Changes in root length at the reproductive stage of maize plants grown in the field and quartz sand. J. Plant Nutr. Soil Sc., 173, 306-314. http://dx.doi.org/10.1002/jpln.200800316

Ong, C. K., Wilson, J., Deans, J.D., Mulayta, J., Raussen, T., \& Wajja-Musukwe, N. (2002). Tree-crop interactions: manipulation of water use and root function. Agr. Water Manage., 53, 171-186. http://dx.doi.org/10.1016/S0378-3774(01)00163-9

Peng, Y., Niu, J., Peng, Z., Zhang, F., \& Li, C. (2010). Shoot growth potential drives N uptake in maize plants and correlates with root growth in the soil. Field Crop. Res., 115, 85-93. http://dx.doi.org/10.1016/j.fcr.2009.10.006

SAS, I., (2002). SAS/STAT version 9.0. user's guide. SAS Institute Cary, NC.

Skelton, L. E., \& Barrett, G. W. (2005). A comparison of conventional and alternative agroecosystems using alfalfa (Medicago sativa) and winter wheat (Triticum aestivum). Reneu. Agr. Food Syst., 20, 38-47. http://dx.doi.org/10.1079/RAF200478

Smith, M. A., \& Carter, P. R. (1998). Strip intercropping corn and alfalfa. J. Prod. Agr., 11, $345-352$. http://dx.doi.org/10.2134/jpa1998.0345

Tennant, D. (1975). A test of a modified line intersect method of estimating root length. J. Ecol., 63, 995-1001.

Tian, Q., Chen, F., Zhang, F., \& Mi, G. (2006). Genotypic difference in nitrogen acquisition ability in maize plants is related to the coordination of leaf and root growth. J. Plant Nutr., 29, 317-330. http://dx.doi.org/10.1080/01904160500476905

Tomm, G. O., van Kessel, C., \& Slinkard, A. E. (1994). Bi-directional transfer of nitrogen between alfalfa and bromegrass: Short and long term evidence. Plant Soil, 164, 77-86. http://dx.doi.org/10.1007/BF00010113

Vance, C. P., Heichel, G. H., Barnes, D. K., Bryan, J. W., \& Johnson, L. E. (1979). Nitrogen fixation, nodule development, and vegetative regrowth of alfalfa (Medicago sativa L.) following harvest. Plant Physiol., $64,1$. http://dx.doi.org/10.1104/pp.64.1.1

Wahla, I. H., Ahmad, R., Ehsanullah, A. A., \& Jabbar, A. (2009). Competitive functions of components crops in some barley based intercropping systems. Int. J. Agric. Biol. (Pakistan), 11, 69-71.

Wardle, D. A., \& Peltzer, D. A. (2003). Interspecific interactions and biomass allocation among grassland plant species. Oikos, 100, 497-506. http://dx.doi.org/10.1034/j.1600-0706.2003.12030.x

Whitmore, A. P., \& Schröder, J. J. (2007). Intercropping reduces nitrate leaching from under field crops without loss of yield: a modelling study. Eur. J. Agron., 27, 81-88. http://dx.doi.org/10.1016/j.eja.2007.02.004

Willey, R. W., \& Rao, M. R. (1980). A competitive ratio for quantifying competition between intercrops. Exp. Agr., 16, 117-125.

Xiao, Y., Li, L., \& Zhang, F. (2004). Effect of root contact on interspecific competition and N transfer between wheat and fababean using direct and indirect $15 \mathrm{~N}$ techniques. Plant Soil, 262, 45-54. http://dx.doi.org/10.1023/b:plso.0000037019.34719.0d

Zhang, F., \& Li, L. (2003). Using competitive and facilitative interactions in intercropping systems enhances crop productivity and nutrient-use efficiency. Plant Soil, $305-312$. http://dx.doi.org/10.1023/A:1022352229863

Zhang, G., Yang, Z., \& Dong, S. (2011). An evaluation of forage potential of an alfalfa/maize intercropping system. Acta Prataculturae Sinica (in Chinese), 20, 117-126.

Zhang, G., Yang, Z., \& Dong, S. (2011). Interspecific competitiveness affects the total biomass in an alfalfa and corn intercropping system. Field Crop. Res., 124, 66-73. http://dx.doi.org/10.1016/j.fcr.2011.06.006

Zhang, X., Huang, G., Bian, X., \& Zhao, Q. (2013). Effects of root interaction and nitrogen fertilization on the chlorophyll content, root activity, photosynthetic characteristics of intercropped soybean and microbial quantity in the rhizosphere. Plant Soil Environ., 59, 80-88. 


\section{Copyrights}

Copyright for this article is retained by the author(s), with first publication rights granted to the journal.

This is an open-access article distributed under the terms and conditions of the Creative Commons Attribution license (http://creativecommons.org/licenses/by/3.0/). 